( Vol. VI, Maret. 2015$)$

\title{
Pengaruh Penyuluhan Kanker Payudara Terhadap Minat Melakukan Pemeriksaan Payudara Sendiri (SADARI ) Pada Wanita Usia Subur (WUS) (Studi Kasus di Rumah Sakit Ibu dan Anak Kirana Sidoarjo, 2014)
}

\author{
Krisnamurti \\ Tenaga Pengajar Prodi. DIII Kebidanan, Universitas PGRI Adi Buana Surabaya
}

\section{ABSTRAK}

Insiden kanker payudara di Indonesia sebesar 26 per 100.000 orang perempuan. Kurangnya pengetahuan mengenai kanker payudara, mengakibatkan sekitar $70 \%$ kasus kanker di Indonesia datang dan menjalani pemeriksaan pada stadium lanjut. Pemeriksaan Payudara Sendiri (SADARI) dapat mendeteksi ca payudara. Tindakan ini sangat penting karena hampir $85 \%$ benjolan di payudara ditemukan oleh penderita sendiri. Penelitian ini bertujuan untuk mengetahui pengaruh penyuluhan kanker payudara terhadap minat melakukan pemeriksaan payudara sendiri (SADARI) pada wanita usia subur (WUS) di RSIA Kirana Sidoarjo

Penelitian ini merupakan penelitian eksperimental jenis one group pre testpost test design dengan pengambilan sampel secara accidental, pada tanggal $9 \mathrm{~s} / \mathrm{d}$ 15 Juni 2014 dan diperoleh sampel sebanyak 43 orang. Pengumpulan data dilakukan dengan wawancara dan pelaksanaan penyuluhan dengan Instrumen kuesioner dan materi penyuluhan. Analisis statistic dengan Wilcoxon Test dengan bantuan komputer

Hasil penelitian diketahui rata-rata skor minat sebelum dilakukan penyuluhan masih rendah yaitu 51,8. Sedangkan berdasarkan kategori minat melakukan pemeriksaan payudara sendiri diketahui bahwa lebih dari separuh wanita usia subur mempunyai minat kategori cukup (31 orang atau 72,1\%). Setelah diberikan penyuluhan tentang kanker payudara dan SADARI selama 1 jam, menunjukkan adanya peningkatan minat wanita usia subur untuk melakukan SADARI yaitu sebanyak 20 orang atau 46,5\%. Hasil uji statistik diketahui bahwa pemberian penyuluhan kanker payudara mempunyai pengaruh yang bermakna terhadap minat melakukan pemeriksaan payudara sendiri (SADARI) pada WUS di RSIA Kirana Sidoarjo $(p<\alpha, 0,05)$. Disarankan kepada para pihak rumah sakit agar memberikan informasi kepada setiap pengunjung rumah sakit terutama wanita usia subur tentang kanker payudara dan SADARI melalui leaflet, poster atau secara langsung melalui Tim Promosi Kesehatan Rumah Sakit (PKRS) secara rutin

Kata kunci : penyuluhan, minat, pemeriksaan payudara sendiri (SADARI)

\section{Pendahuluan}

WHO pada tahun 2005

melaporkan bahwa sebanyak 506.000 wanita meninggal disebabkan oleh kanker payudara. Sedangkan di Indonesia menurut profil kesehatan Departemen Kesehatan Republik Indonesia tahun 2007 kanker tertinggi yang diderita wanita Indonesia adalah kanker payudara dengan angka kejadian 26 per 100.000 perempuan. Walaupun insiden kanker payudara meningkat, angka mortalitas menurun secara signifikan dari tahun 1992 hingga 1996 karena deteksi dini dan pengobatan yang lebih baik. (Depkes, 2008).

Berdasarkan data Globocan, International Agency Research Cancer I IARC (2002), didapatkan perkiraan insiden kanker payudara di Indonesia sebesar 26 per 100.000 perempuan dan kanker leher rahim sebesar 16 per 100.000 perempuan. Sementara berdasarkan data dari Badan Registrasi Kanker Ikatan Dokter Ahli 
Patologi Indonesia (IAPI), tahun 1998 pada 13 rumah sakit di Indonesia kanker leher rahim menduduki peringkat pertama dari seluruh kasus kanker sebesar $17,2 \%$ diikuti kanker payudara $12,2 \%$ (Depkes, 2008).

Kurangnya

pengetahuan

mengenai kanker payudara ditambah dengan gejala permulaan kanker payudara yang sering tidak disadari atau dirasakan dengan jelas oleh penderita, mengakibatkan sekitar $70 \%$ kasus kanker di Indonesia datang dan menjalani pemeriksaan pada stadium lanjut. Hal itulah yang menjadi penyebab tingginya angka kematian akibat kanker payudara.Padahal, kanker payudara seperti kanker pada umumnya dimana kesuksesan pengobatannya sangat ditentukan oleh deteksi pada stadium awal. (Depkes, 2008)

Untuk mendeteksi adanya kanker payudara dapat dilakukan dengan Pemeriksaan Payudara Sendiri (SADARI). Tindakan ini sangat penting karena hampir $85 \%$ benjolan di payudara ditemukan oleh penderita sendiri. Pada wanita normal, American Cancer Society menganjurkan wanita berusia diatas 20 tahun untuk melakukan SADARI setiap satu bulan, usia 35-40 tahun melakukan mamografi, diatas 40 tahun melakukan check up pada dokter ahli, lebih dari 50 tahun check up rutin dan mamografi setiap tahun, dan wanita yang beresiko tinggi pemeriksaan dokter lebih sering dan rutin. Insiden kanker meningkat seiring dengan pertambahan usia, oleh karena itu kesadaran akan pentingnya upaya perilaku SADARI sebagai deteksi dini kanker payudara perlu ditingkatkan pula. (Varney, 2008)

Jumlah penderita Ca Mammae di Rumah Sakit di Kabupaten Sidoarjo pada tahun 2010 berdasarkan laporan Yayasan Kanker Indonesia cabang Sidoarjo adalah sebanyak 182 orang yang menjalani perawatan, diantara jumlah tersebut, sekitar $30-50 \%$ penderita kanker payudara.

Meskipun kampanye tentang kanker payudara dan SADARI telah banyak dilakukan baik secara langsung maupun tidak langsung, namun masih banyak masyarakat yang kurang mengetahui dan memberikan respon yang baik tentang kanker payudara dan SADARI. Dari studi pendahuluan peneliti dengan wawancara pada sepuluh wanita dewasa pengunjung Rumah Sakit lbu dan Anak (RSIA) Kirana Sidoarjo pada bulan Mei 2014 dapat diketahui bahwa dua diantaranya mempunyai pengetahuan yang cukup tentang SADARI yang diperolehnya dari media massa, dan delapan lainnya hampir tidak mengetahui tentang SADARI baik cara, manfaat serta waktu melakukan prosedur SADARI. Dari studi tersebut juga didapatkan hasil sementara dari sikapnya, bahwa mereka cenderung kurang tanggap melakukan SADARI karena menganggap hal tersebut kurang penting. Hal ini bisa terjadi diakibatkan kurangnya informasi tentang pentingya SADARI, selain itu menurut Kardinah (2007), minimnya informasi dan upaya publikasi mengenai antisipasi dini Ca-Mammae membuat penemuan dan penanganan kanker belum bisa terkelola dengan baik.

Dari pengamatan peneliti sampai saat ini di RSIA Kirana Sidoarjo masih jarang ada penyuluhan tentang CaMammae dan deteksi dini $\mathrm{Ca}$ Mammae, jika ada penyuluhan tersebut tidak di diketahui pasti penerima informasi sudah mengalami peningkatan pengetahuan maupun sikapnya terhadap SADARI. Dari berbagai uraian di atas peneliti tertarik untuk meneliti "Pengaruh Penyuluhan Kanker Payudara Terhadap Minat Melakukan Pemeriksaan Payudara Sendiri (SADARI) pada Wanita Usia Subur (WUS)". 
Berdasarkan uraian latar belakang tersebut diatas, maka dapat dirumuskan masalahnya yaitu: Adakah pengaruh penyuluhan kanker payudara terhadap minat melakukan pemeriksaan payudara sendiri (SADARI) pada wanita usia subur (WUS) di RSIA Kirana Sidoarjo ? .

\section{Metode Penelitian \\ Desain Penelitian}

Berdasarkan tujuan penelitian maka desain penelitian yang digunakan adalah desain penelitian eksperimental dengan pendekatan praeksperimental one group pre testpost test dengan bentuk rancangan ini adalah sebagai berikut :

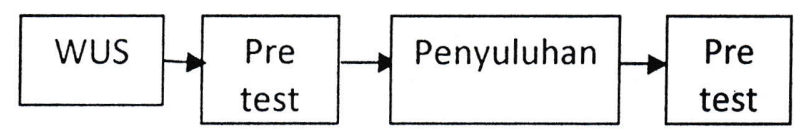

\section{Tempat dan Waktu Penelitian}

Penelitian dilaksanakan di Rumah Sakit Ibu dan Anak Kirana Sidoarjo, pada tanggal $9-15$ Juni 2014

\section{Populasi dan Sampling Desain}

Populasi dalam penelitian ini adalah seluruh Wanita Usia Subur (WUS) yang berkunjung ke Rumah Sakit Ibu dan Anak Kirana Sidoarjo pada tanggal 9 s/d 15 Juni 2014

Sampel penelitian ini adalah sebagian wanita usia subur yang berkunjung ke RSIA Kirana Sidoarjo pada tanggal 9 s/d 15 Juni 2014 yang memenuhi kriteria inklusi sebagai berikut : 1) lbu yang termasuk wanita usia subur (WUS) yaitu dengan usia 20-45 tahun, 2) Wanita usia subur yang bisa membaca dan dapat berkomunikasi dengan baik. Dan 3) Wanita usia subur yang bersedia menjadi responden. Pengambilan sampel dilakukan secara accidental, yaitu berdasarkan jumlah pengunjung yang datang pada tanggal 9 s/d 15 Juni 2014 yang memenuhi kriteria yang telah ditentukan.

\section{Identifikasi Variabel}

Variabel bebas atau independen dalám penelitian ini adalah penyuluhan kanker payudara, sedangkan variabel dependen dalam penelitian ini adalah Minat melakukan pemeriksaan payudara sendiri (SADARI) pada WUS.

\section{Instrumen Penelitian}

Proses pengumpulan data dilakukan dengan menggunakan kuesioner. Data dalam kuesioner 18 pertanyaan dengan pilihan jawaban SS, S, R, TS, STS atau Sangat perlu, perlu, ragu, tidak perlu, sangat tidak perlu. Pada pernyataan Favourable skor SS (sangat Setuju) diberi skor 5, S (Setuju) diberi skor 4, R (Ragu-ragu) diberi skor 3, TS (Tidak Setuju) diberi skor 2, STS (sangat tidak setuju) diberi skor 1. Pada pernyataan unfavourable STS diberi skor 5, TS skor 4, R Skor 3, S skor 2,SS skor 1.

\section{Pengumpulan Data}

Pengumpulan data dalam penelitian ini dilakukan dengan cara menyebar kuesioner kepada sejumlah responden untuk mendapatkan informasi atau jawaban. Pengambilan datanya dilakukan 2 tahap, yaitu sebelum dan sesudah diberi penyuluhan dengan cara memberikan instrument kuesioner untuk diisi oleh responden dengan memilih jawaban sesuai minat responden. Data primer dalam penelitian ini berupa data hasil penelitian yang berupa jawaban kuesioner sebelum dilakukan penyuluhan dan pelatihan dengan sesudah diberi penyuluhan dan pelatihan.

\section{Analisis Data}

Data setelah terkumpul,
dilakukan proses editing, koding,
ditabulasi dan dimasukkan dalam
program komputer (entry), kemudian
dianalisis, dengan cara deskriptif dan
analitik. Untuk data yang dianalisus


secara analitik akan dilakukan uji statistik wilcoxon test, untuk melihat adanya pengaruh antara variable penyuluhan terhadap minat melakukan pemeriksaan payudara sendiri. Jika nilai $p \leq 0,05$ berarti terdapat pengaruh variable penyuluhan terhadap minat melakukan SADARI, jika nilai $p>0,05$ berarti tidak terdapat pengaruh variable penyuluhan terhadap minat melakukan pemeriksaan payudara sendiri (SADARI)

\section{HASIL PENELITIAN}

Berdasarkan hasil pengumpulan data penelitian pada 43 responden wanita usia subur di Rumah Sakit Ibu dan Anak Kirana Sidoarjo, pada bulan Juni 2014, maka dapat diuraikan tentang data umum dan data khusus penelitian yang sesuai dengan tujuan penelitian. Adapun uraian hasil penelitian dapat dijelaskan sebagai berikut:

\section{Data Umum Penelitian}

Hasil pengumpulan data pada 43 wanita usia subur di RSIA Kirana Sidoarjo pada bulan Juni 2014 dapat diketahui bahwa, rata-rata umur wanita usia subur adalah 35,2 tahun, dengan umur termuda 25 tahun dan umur tertua 44 tahun. Sedangkan berdasarkan kelompok umur wanita usia subur dapat dijelaskan bahwa sebagian besar wanita usia subur di RSIA Kirana Sidoarjo berusia antara 30 - 40 tahun yaitu sebanyak 23 orang atau $53,5 \%$

Berdasarkan tingkat pendidikan wanita usia subur yang diteliti di RSIA Kirana Sidoarjo, separuhnya (16 orang atau $37,2 \%$ ) telah berpendidikan SMA atau sederajat dan bahkan sebanyak 4 orang atau $9,3 \%$ telah menempuh pendidikan perguruan tinggi

Berdasarkan hasil penelitian terhadap 43 orang wanita usia subur di RSIA Kirana Sidoarjo diketahui bahwa sebagian besar atau 26 orang $(60,5 \%)$ sebagai ibu rumah tangga.

\section{Data Khusus Penelitian}

Data khusus penelitian yang dapat diuraikan pada bab ini adalah tentang minat melakukan pemeriksaan payudara sendiri (SADARI) dan pengaruh penyuluhan terhadap minat melakukan pemerikasan payudara sendiri (SADARI) wanita usia subur di RSIA Kirana Sidoarjo

\section{Tabel 5.1 Distribusi Minat Melakukan SADARI pada WUS Sebelum Dilakukan Penyuluhan di RSIA Kirana Sidoarjo pada bulan Juni 2014}

\begin{tabular}{ccccccc}
\hline & Kategori & & & \multicolumn{2}{c}{ Skor Minat } \\
\cline { 3 - 7 } & Minat & $n$ & $\%$ & $\begin{array}{c}\text { Rata- } \\
\text { rata }\end{array}$ & Min & Max \\
\hline 1 & Kurang & 2 & 4,7 & $51,8 \pm 28,0$ & 66,0 \\
2 & Cukup & 31 & 72,1 & 8,7 & & \\
3 & Baik & 10 & 23,3 & & & \\
\hline
\end{tabular}

Berdasarkan Minat melakukan pemeriksaan payudara sendiri (SADARI) wanita usia subur sebelum dilakukan penyuluhan tentang kangker payudara di RSIA Kirana Sidoarjo diketahui bahwa rata-rata skor minat adalah 51,8 dengan skor terendah 28,0 dan skor maksimal 66,0. Sedangkan berdasarkan kategori minat WUS diketahui bahwa lebih dari separuh wanita usia subur mempunyai minat kategori cukup yaitu sebanyak 31 orang atau $72,1 \%$

Tabel 5.2. Tabel Silang Antara Umur dengan Minat WUS Untuk SADARI di RSIA Kirana Sidoarjo pada bulan Juni 2014

\begin{tabular}{ccccccc}
\hline & \multicolumn{5}{c}{ Kategori Minat } \\
\cline { 2 - 7 } Kelompok & \multicolumn{1}{c}{ Kurang } & \multicolumn{2}{c}{ Cukup } & \multicolumn{2}{c}{ Baik } \\
\cline { 2 - 7 } Umur WUS & $\mathrm{n}$ & $\%$ & $\mathrm{n}$ & $\%$ & $\mathrm{n}$ & $\%$ \\
\hline $20-30$ th & 0 & 0,0 & 8 & 72,7 & 3 & 27,3 \\
$31-40$ th & 1 & 4,3 & 16 & 69,6 & 6 & 26,1 \\
$41-45$ th & 1 & 11,1 & 7 & 77,8 & 1 & 11,1 \\
\hline Total & 2 & 4,7 & 31 & 72,1 & 10 & 23,3 \\
\hline
\end{tabular}


Berdasarkan hasil penelitian dapat dijelaskan bahwa ada kecenderungan pada wanita usia subur yang berusia lebih tua, cenderung mempunyai minat yang kurang untuk melakukan pemeriksaan payudara sendiri (SADARI). Dari 9 wanita usia subur yang berusia 41-45 tahun, masing-masing sebanyak 1 orang atau $11,1 \%$ mempunyai minat yang kurang dan baik, dan sebanyak 7 orang atau $77,8 \%$ mempunyai minat kategori cukup. Sedangkan dari 11 orang wanita usia subur yang berusia 20-30 tahun, sebanyak 8 orang atau $72,7 \%$ mempunyai minat kategori cukup dan sebanyak 3 orang atau $27,3 \%$ mempunyai minat yang baik untuk melakukan pemeriksaan payudara sendiri (SADARI)

Tabel 5.3. Tabel

Silang

Pendidikan WUS dengan Minat SADARI di RSIA Kirana Sidoarjo pada bulan Juni 2014

\begin{tabular}{ccccccc}
\hline \multirow{3}{*}{$\begin{array}{c}\text { Pendidikan } \\
\text { WUS }\end{array}$} & \multicolumn{6}{c}{ Kategori Minat } \\
\cline { 2 - 7 } & \multicolumn{2}{c}{ Kurang } & \multicolumn{2}{c}{ Cukup } & \multicolumn{3}{c}{ Baik } \\
\cline { 2 - 7 } & $\mathrm{n}$ & $\%$ & $\mathrm{n}$ & $\%$ & $\mathrm{n}$ & $\%$ \\
\hline SD & 2 & 20,0 & 6 & 60,0 & 2 & 20,0 \\
SMP & 0 & 0,0 & 11 & 84,6 & 2 & 15,4 \\
SMA & 0 & 0,0 & 10 & 62,5 & 6 & 37,5 \\
PT & 0 & 0,0 & 4 & 100,0 & 0 & 0,0 \\
\hline Total & 2 & 4,7 & 31 & 72,1 & 10 & 23,3 \\
\hline
\end{tabular}

Tabel 5.3 tersebut menjelaskan

bahwa ada kecenderungan pada wanita usia subur yang berpendidikan $S D$, cenderung mempunyai minat yang kurang untuk melakukan pemeriksaan payudara sendiri (SADARI). Dari 10 wanita usia subur yang pendidikannya $\mathrm{SD}$, masing-masing sebanyak 2 orang atau 20,0\% mempunyai minat yang kurang dan baik, sedangkan sebanyak 6 orang atau $60,0 \%$ mempunyai minat kategori cukup. Sedangkan dari 16 orang wanita usia subur yang berpendidikan SMA, sebanyak 10 orang atau $62,5 \%$ mempunyai minat kategori cukup dan sebanyak 6 orang atau $37,5 \%$ mempunyai minat yang baik untuk melakukan pemeriksaan payudara sendiri (SADARI).

\section{Tabel 5.4. Tabel Silang Antara Pekerjaan dengan Minat WUS Untuk Melakukan SADARI di RSIA Kirana Sidoarjo pada bulan Juni 2014}

\begin{tabular}{ccccccc}
\hline \multirow{2}{*}{$\begin{array}{c}\text { Pekerjaan } \\
\text { WUS }\end{array}$} & \multicolumn{5}{c}{ Kategori Minat } \\
\cline { 2 - 7 } & \multicolumn{2}{c}{ Kurang } & \multicolumn{2}{c}{ Cukup } & \multicolumn{2}{c}{ Baik } \\
\cline { 2 - 7 } & $\mathrm{n}$ & $\%$ & $\mathrm{n}$ & $\%$ & $\mathrm{n}$ & $\%$ \\
\hline IRT & 2 & 7,7 & 16 & 61,5 & 8 & 30,8 \\
Swasta & 0 & 0,0 & 2 & 100,0 & 0 & 0,0 \\
Wiraswasta & 0 & 0,0 & 9 & 81,8 & 2 & 18,2 \\
PNS & 0 & 0,0 & 4 & 100,0 & 0 & 0,0 \\
\hline Total & 2 & 4,7 & 31 & 72,1 & 10 & 23,3 \\
\hline
\end{tabular}

Berdasarkan tabel 5.4 tersebut menjelaskan bahwa pada wanita usia subur yang mempunyai pekerjaan swasta dan PNS, seluruhnya (100,0\%) mempunyai minat kategori cukup, sedangkan pada 26 orang responden yang tidak bekerja atau sebagai ibu rumah tangga, ditemukan sebanyak 8 orang atau $30,8 \%$ mempunyai minat kategori baik, 16 orang atau $61,5 \%$ mempunyai minat kategori cukup dan sebanyak 2 orang atau $7,7 \%$ minat untuk melakukan pemeriksaan payudara sendiri kategori kurang.

\section{Pengaruh Penyuluhan Terhadap Minat WUS Untuk Melakukan Pemeriksaan Payudara Sendiri}

Setelah dikumpulkan data pre test tentang minat wanita usia subur melakukan pemeriksaan peyudara sendiri (SADARI), dilanjutkan dengan pemberian materi penyuluhan selama kurang lebih 1 . jam dengan menggunakan media leaflet dan LCD proyektor dengan materi tentang kanker payudara yang meliputi Pengertian CA Mamae, Faktor Penyebab CA Mamae, Penatalaksanaan CA Mamae, Gejala CA Mamae, Golongan Resiko CA Mamae, dan Metode Deteksi Dini. Sedangkan materi tentang 
pemeriksaan payudara sendiri (SADARI) meliputi Pengertian SADARI, Manfaat SADARI, Waktu dilakukan SADARI, dan Cara Pemeriksaan SADARI. Adapun minat wanita usia subur untuk melakukan pemeriksaan payudara sendiri setelah diberikan penyuluhan dapat dilihat pada tabel berikut ini

Tabel 5.5 Minat Pemeriksaan Sendiri WUS Melakukan Payudara Penyuluhan di RSIA Kirana Sidoarjo pada bulan Juni 2014

\begin{tabular}{ccccccc}
\hline No & $\begin{array}{c}\text { Kategori } \\
\text { Minat }\end{array}$ & $n$ & $\%$ & \multicolumn{2}{c}{ Skor Minat } \\
\cline { 3 - 6 } & & & $\begin{array}{c}\text { Rata- } \\
\text { rata }\end{array}$ & Min Max \\
\hline 1 & Kurang & 0 & 0,0 & $62,1 \pm$ & 54,0 & 71,0 \\
2 & Cukup & 13 & 30,2 & 4,9 & & \\
3 & Baik & 30 & 69,8 & 4,9 & \\
\hline TOTAL & 43 & 100,0 & & & \\
\hline
\end{tabular}

Berdasarkan minat melakukan pemeriksaan payudara sendiri (SADARI) wanita usia subur setelah dilakukan penyuluhan diketahui bahwa rata-rata skor minat adalah $62,1 \pm 4,9$ dengan skor terendah 54,0 dan skor maksimal 71,0 . Sedangkan berdasarkan kategori minat wanita usia subur diketahui bahwa lebih dari separuh wanita usia subur mempunyai minat kategori baik yaitu sebanyak 30 orang atau $69,8 \%$

Sedangkan perubahan minat melakukan pemeriksaan payudara sendiri (SADARI) wanita usia subur antara sebelum dengan sesudah diberikan penyuluhan tentang kanker payudara dan pemeriksaan payudara sendiri di Rumah Sakit Ibu dan Anak Kirana Sidoarjo dapat dilihat pada tabel berikut ini

\section{Tabel 5.6 Distribusi Perubahan Minat WUS Antara Sebelum dengan Sesudah Penyuluhan di RSIA Kirana Sidoarjo pada bulan Juni 2014}

\begin{tabular}{cccc}
\hline No & $\begin{array}{c}\text { Perubahan } \\
\text { Minat }\end{array}$ & Jumlah & Prosentase \\
\hline 1 & Turun & 0 & 0,0 \\
2 & Tetap & 23 & 53,5 \\
3 & Naik & 20 & 46,5 \\
\hline & TOTAL & 43 & 100,0 \\
\hline
\end{tabular}

Berdasarkan tabel tersebut dapat dijelaskan bahwa lebih dari separuh atau 23 orang $(53,5 \%)$ minat wanita usia subur untuk melakukan pemeriksaan payudara sendiri (SADARI) termasuk kategori tetap, sedangkan sebanyak 20 orang atau $46,5 \%$ naik atau meningkat setelah diberikan penyuluhan tentang kanker payudara dan pemeriksaan payudara sendiri selama kurang lebih 1 jam.

\section{Tabel 5.7. Pengaruh Pemberian Penyuluhan Kanker Payudara terhadap Minat Untuk Melakukan Pemeriksaan Payudara Sendiri (SADARI) pada Wanita usia subur di RSIA Kirana Sidoarjo, bulan Juni 2014}

\begin{tabular}{|c|c|c|c|c|c|c|}
\hline \multirow{3}{*}{$\begin{array}{c}\text { Kategori } \\
\text { Minat } \\
\text { SADARI }\end{array}$} & \multicolumn{4}{|c|}{ Pengumpulan Data Minat } & \multirow{2}{*}{\multicolumn{2}{|c|}{$\begin{array}{l}\text { Hasil Uji } \\
\text { Statistik }\end{array}$}} \\
\hline & \multicolumn{2}{|c|}{$\begin{array}{c}\text { Sebelum } \\
\text { Penyuluhan }\end{array}$} & \multicolumn{2}{|c|}{$\begin{array}{c}\text { Sesudah } \\
\text { Penyuluhan }\end{array}$} & & \\
\hline & $n$ & $\%$ & $n$ & $\%$ & $p$ & Ket \\
\hline Kurang & 2 & 4,7 & 0 & 0,0 & & \\
\hline Cukup & 31 & 72,1 & 13 & 30,2 & & Signi \\
\hline Baik & 10 & 23,3 & 30 & 69,8 & & ficant \\
\hline Total & 43 & 100,0 & 43 & 100,0 & & \\
\hline
\end{tabular}

Pada tabel 5.7 tersebut juga menunjukkan bahwa ada perubahan kategori minat yang cukup nyata antara sebelum dengan sesudah diberikan penyuluhan tentang kanker peyudara dan pemeriksaan payudara sendiri pada wanita usia subur di RSIA Kirana Sidoarjo. Sebelum diberikan 
penyuluhan, sebagian besar (31 orang atau $72,1 \%$ ) minat wanita usia subur untuk melakukan pemeriksaan payudara sendiri (SADARI) termasuk kategori cukup, namun setelah diberikan penyuluhan, diketahui bahwa lebih dari separuh (30 orang atau $69,8 \%$ mempunyai minat untuk melakukan pemeriksaan payudara sendiri kategori baik.

Berdasarkan analisa statistik dengan wilcoxon test diketahui bahwa nilai $p=0,000<\alpha 0,05$. Hal ini dapat disimpulkan bahwa pemberian penyuluhan tentang kanker payudara dan pemeriksaan payudara sendiri (SADARI) mempunyai pengaruh yang bermakna terhadap minat untuk melakukan pemeriksaan payudara sendiri (SADARI) di Rumah Sakit lbu dan Anak Kirana Sidoarjo

\section{Pembahasan}

Minat Wanita Usia SUbur Melakukan Pemeriksaan Payudara Sendiri (SADARI) di RSIA Kirana Sidoarjo

Minat seseorang dapat timbul akibat adanya daya tarik dari luar dan juga datang dari hati sanubari masing-masing. Minat yang besar terhadap sesuatu merupakan modal yang besar artinya untuk mencapai atau memperoleh benda atau tujuan yang diinginkan itu (Dalyono, 2001).

Berdasarkan Minat melakukan pemeriksaan payudara sendiri (SADARI) wanita usia subur sebelum dilakukan penyuluhan tentang kangker payudara di RSIA Kirana Sidoarjo diketahui bahwa lebih dari separuh wanita usia subur mempunyai minat kategori cukup yaitu sebanyak 31 orang atau $72,1 \%$. Keadaan tersebut terjadi karena sebagian besar responden yang ada belum banyak mendapatkan informasi yang lengkap dan benar terkait dengan kanker payudara dan pemeriksaan payudara sendiri. Selain itu minat masyarakat untuk melakukan pemeriksaan SADARI masih sangat rendah, hal ini banyak dipengaruhi oleh ketidaktahuan wanita akan bahaya kánker payudara, sedangkan pengetahuan masih dipengaruhi oleh pendidikan maupun ekonomi. Selain masih banyaknya anggapan bahwa penyakit kanker tidak bisa disembuhkan sehingga ada rasa takut untuk melakukan SADARI.

Namun berdasarkan hasil penelitian diketahui bahwa ada kecenderungan pada wanita usia subur yang berusia lebih tua, cenderung mempunyai minat yang kurang untuk melakukan pemeriksaan payudara sendiri (SADARI). Dari 9 wanita usia subur yang berusia 41-45 tahun, masing-masing sebanyak 1 orang atau $11,1 \%$ mempunyai minat yang kurang dan baik, dan sebanyak 7 orang atau $77,8 \%$ mempunyai minat kategori cukup. Sedangkan dari 11 orang wanita usia subur yang berusia 20-30 tahun, sebanyak 8 orang atau $72,7 \%$ mempunyai minat kategori cukup dan sebanyak 3 orang atau $27,3 \%$ mempunyai minat yang baik untuk melakukan pemeriksaan payudara sendiri (SADARI),

$\mathrm{Hal}$ ini terjadi karena pada responden yang berusia lebih dari 41 tahun namun minatnya kurang karena kurangnya pengetahuan tentang bahaya kanker payudara atau ketidak tahuan tentang cara pencegahan kanker payudara dengan pemeriksaan payudara sendiri. Hal ini terbukti setelah diberikan informasi melalui penyuluhan tentang kanker payudara dan pemeriksaan payudara sendiri, minat responden tersebut menjadi kategori baik

Menurut Hurlock (2000) minat seseorang dipengaruhi oleh umur, jenis kelamin, pengalaman, status ekonomi, tanggungjawab, pengetahuan dan pindidikan. Umur mempengaruhi minat seseorang karena minat muncul sejak masa bayi, dengan diawali minat untuk bermain. Semakin bertambah usia seseorang 
maka akan muncul minat yang baru bahkan minat lamanya akan berangsur-angsur menghilang. Selain itu, perubahan pada minat juga dipengaruhi oleh lingkungan, kelompok, dan peran yang ada dalam dirinya karena adanya perbedaan dalam kemampuan dan pengalaman. Status ekonomi membaik, orang cenderung memperluas minat mereka. Sebaliknya jika status ekominya memburuk, maka orang akan mempersempit minatnya.

Pendidikan seseorang juga akan mempengaruhi minat, hal ini disebabkan oleh rasa ingin tahu yang dimiliki tiap orang (Hurlock, 2004). Pendidikan dapat diperoleh baik secara formal maupun non formal dan salah satu bentuk pendidikan nonformal yaitu penyuluhan tentang payudara, sehingga pendapat Hurlock (2004) terbukti dalam penelitian ini yang hasilnya menunjukkan bahwa ada kecenderungan pada wanita usia subur yang berpendidikan SD, cenderung mempunyai minat yang kurang untuk melakukan pemeriksaan payudara sendiri (SADARI). Dari 10 wanita usia subur yang pendidikannya SD, masing-masing sebanyak 2 orang atau $20,0 \%$ mempunyai minat yang kurang dan baik, sedangkan sebanyak 6 orang atau $60,0 \%$ mempunyai minat kategori cukup. Sedangkan dari 16 orang wanita usia subur yang berpendidikan SMA, sebanyak 10 orang atau $62,5 \%$ mempunyai minat kategori cukup dan sebanyak 6 orang atau $37,5 \%$ mempunyai minat yang baik untuk melakukan pemeriksaan payudara sendiri (SADARI).

Pendidikan merupakan salah satu faktor yang menentukan pengetahuan dan persepsi seseorang terhadap pentingnya sesuatu hal termasuk pentingnya pemberian ASI bagi bayi. Robert M. Gagne (1998) mengemukakan bahwa proses pendidikan akan meningkatkan kemampuan seseorang dalam kemahiran intelektual baik dalam memberi persepsi konsep atau mengungkapkan hubungan yang terdapat antara beberapa konsep serta meningkatkan sikap dan kemampuan motorik. Pendidikan diperlukan untuk mendapatkan informasi, misalnya halhal yang menunjang kesehatan sehingga dapat meningkatkan kualitas hidup. Hal ini juga didukung oleh IB. Mantra yang dikutip oleh Notoatmojo (1995), yang menyatakan bahwa pendidikan dapat mempengaruhi seseorang termasuk juga perilaku seseorang akan pola hidup terutama dalam memotivasi untuk sikap berperan serta dalam pembangunan kesehatan.

Apabila status ekonomi membaik, orang cenderung memperluas minat mereka untuk mencakup hal yang semula belum mampu mereka laksanakan. Sebaliknya kalau status ekonomi mengalami kemunduran karena tanggung jawab keluarga atau usaha yang kurang maju, maka orang cenderung untuk mempersempit minat mereka. Hasil penelitian menunjukkan bahwa pada wanita usia subur yang mempunyai pekerjaan swasta dan PNS, seluruhnya $(100,0 \%)$ mempunyai minat kategori cukup, sedangkan pada 26 orang responden yang tidak bekerja atau sebagai ibu rumah tangga, ditemukan sebanyak 8 orang atau $30,8 \%$ mempunyai minat kategori baik, 16 orang atau $61,5 \%$ mempunyai minat kategori cukup dan sebanyak 2 orang atau $7,7 \%$ minat untuk melakukan pemeriksaan payudara sendiri kategori kurang.

Hal ini terjadi karena lingkungan pekerjaan merupakan salah satu kondisi yang ada di sekitar seseorang yang dapat mempengaruhi perkembangan dan perilaku orang atau kelompok. Lingkungan adalah input kedalam diri seseorang sehingga sistem adaptif yang melibatkan baik faktor internal maupun faktor eksternal. 
Seseorang yang hidup dalam lingkungan pekerja akan cenderung mengikuti lingkungannya.

\section{Pengaruh Penyuluhan Terhadap Minat Wanita Usia Subur Melakukan Pemeriksaan Payudara Sendiri} (SADARI) di RSIA Kirana Sidoarjo

Setelah diberikan penyuluhan selama \pm 1 jam dengan menggunakan media leaflet dan LCD proyektor dengan materi tentang kanker payudara yang meliputi Pengertian CA Mamae, Faktor Penyebab CA Mamae, Penatalaksanaan CA Mamae, Gejala CA Mamae, Golongan Resiko CA Mamae, dan Metode Deteksi Dini. Sedangkan materi tentang pemeriksaan payudara sendiri (SADARI) meliputi Pengertian SADARI, Manfaat SADARI, Waktu dilakukan SADARI, dan Cara Pemeriksaan SADARI. Hasilnya menunjukkan perubahan minat yang lebih baik untuk melakukan pemeriksaan payudara sendiri (SADARI)

Penyuluhan pada setiap wanita diprioritaskan mengenai bagaimana dan kapan melakukan pemeriksaan payudara mereka sendiri. Diperkirakan bahwa hanya $25 \%$ $30 \%$ wanita yang melakukan pemeriksaan payudara sendiri dengan baik dan teratur setiap bulannya. Wanita yang lebih muda yang mungkin mempunyai benjolan pada payudara mereka ternyata kesulitan dalam melakukan SADARI. Bahkan wanita yang melakukan SADARI mungkin menunda untuk mencari bantuan medis karena ketakutan faktor ekonomi, kurang pendidikan, enggan untuk bertindak jika tidak terasa nyeri, faktor- faktor psikologis dan kesopanan (Smeltzer, 2001).

Sedangkan perubahan minat melakukan pemeriksaan payudara sendiri (SADARI) wanita usia subur antara sebelum dengan sesudah diberikan penyuluhan tentang kanker payudara di Rumah Sakit lbu dan Anak Kirana Sidoarjo dapat dijelaskan bahwa lebih dari separuh atau 23 orang $(53,5 \%)$ minat wanita usia subur untuk melakukan pemeriksaan payudara sendiri (SADARI) termasuk kategori tetap, sedangkan sebanyak 20 orang atau $46,5 \%$ naik atau meningkat setelah diberikan penyuluhan tentang kanker payudara dan pemeriksaan payudara sendiri selama kurang lebih 1 jam.

Dengan demikian penyuluhan tentang kanker payudara yang dilakukan memberikan pengaruh yang baik terhadap minat melakukan pemeriksaan payudara sendiri (SADARI). Pemberian penyuluhan telah meningkatkan minat melakukan pemeriksaan payudara sendiri (SADARI), hal ini sesuai dengan pendapat Emilia, O (2008: 67), bahwa salah satu cara untuk meningkatkan pengetahuan adalah dengan pemberian penyuluhan dan dengan meningkatnya pengetahuan dapat mempengaruhi minat.

Keadaan tersebut juga tunjukkan bahwa ada perubahan kategori minat yang cukup nyata antara sebelum dengan sesudah diberikan penyuluhan tentang kanker peyudara dan pemeriksaan payudara sendiri pada wanita usia subur di RSIA Kirana Sidoarjo. Sebelum diberikan penyuluhan, sebagian besar (31 orang atau $72,1 \%$ ) minat wanita usia subur untuk melakukan pemeriksaan payudara sendiri (SADARI) termasuk kategori cukup, namun setelah diberikan penyuluhan, diketahui bahwa lebih dari separuh (30 orang atau $69,8 \%$ mempunyai minat untuk melakukan pemeriksaan payudara sendiri kategori baik. Berdasarkan analisa statistik dengan wilcoxon test diketahui bahwa nilai $\mathrm{p}=0,000<\alpha$ 0,05 . Hal ini dapat disimpulkan bahwa pemberian penyuluhan tentang kanker payudara dan pemeriksaan payudara sendiri (SADARI) mempunyai 
pengaruh yang bermakna terhadap minat untuk melakukan pemeriksaan payudara sendiri (SADARI) di Rumah Sakit Ibu dan Anak Kirana Sidoarjo

Meningkatnya

responden setelah

diberikan

penyuluhan dikarenakan pengetahuan responden mengenai kanker payudara sudah cukup baik, pengetahuan yang baik mengenai kanker payudara, dapat meningkatkan minat responden juga untuk melakukan SADARI seperti yang dikatakan sawarno (2005) bahwa minat responden akan diperolah dari pengetahuan yang baik. Jadi pengetahuan yang baik mampu menimbulkan minat yang akhirnya seseorang mau untuk melakukan suatu tindakan

Perubahan pada minat wanita usia subur untuk melakukan pemeriksaan payudara sendiri tersebut tampaknya juga dipengaruhi oleh umur, jenis kelamin, pengalaman, tanggung jawab, dan pendidikan. Status ekonomi juga berpengaruh terhadap minat seseorang karena jika status ekonomi membaik, orang cenderung memperluas minat mereka. Sebaliknya jika status ekonomi memburuk, maka orang akan mempersempit minatnya.

Salah satu cara yang dapat dilakukan untuk mengurangi angka kejadian kanker payudara adalah dengan pemeriksaan payudara sendiri (SADARI). Pemeriksaan payudara sendiri merupakan deteksi dini kanker payudara yang paling banyak dianjurkan bagi setiap wanita. Tindakan ini sangat penting karena hampir 85 persen benjolan di payudara ditemukan oleh penderita sendiri. Caranya sangat mudah dan murah karena dilakukan oleh diri sendiri, tidak menimbulkan rasa sakit, tidak mengakibatkan kerusakan jaringan dan dapat mendeteksi tumor sekecil apapun karena ujung jari tangan kita mempunyai kepekaan untuk bisa meraba massa yang berukuran satu centimeter (1 cm) (Cahyani, 2000). - Pemeriksaan ini dilakukan minimal satu bulan sekali setelah haid, sebab pengaruh proses haid terhadap payudara sudah tidak ada.

Beberapa penelitian memang menunjukkan SADARI tidak menurunkan angka kematian akibat kanker payudara, namun kombinasi antara SADARI dan mammografi masih dibutuhkan untuk menurunkan risiko kematian akibat kanker payudara. Kearney dan Murray (2006) mengemukakan bahwa keunggulan SADARI adalah dapat menemukan tumor I benjolan payudara pada stadium awal, penemuan awal benjolan dipakai sebagai rujukan melakukan mammografi untuk mendeteksi interval kanker, mendeteksi benjolan yang tidak terlihat saat melakukan mammografi dan menurunkan kematian akibat kanker payudara. Bagi setiap wanita dianjurkan untuk melakukan pemeriksaan payudara sendiri (SADARI) secara teratur khusunya bagi mereka yang berumur diatas 20 tahun. Pada wanita yang berumur diatas 20 tahun atau mereka yang berisiko tinggi, agar mengambil peran aktif dalam mendeteksi dini ada atau tidaknya kanker payudara, yaitu kepada mereka yang secara rutin untuk melakukan pemeriksaan payudara sendiri (SADARI) karena dalam penelitian ternyata $75 \%$ hingga $85 \%$ kanker payudara ditemukan disaat dilakukan pemeriksaan payudara sendiri (Hawari, 2004).

Salah satu cara yang efektif dan efisien dalam upaya pencegahan atau deteksi dini adanya kanker payudara adalah dengan SADARI secara rutin. Sebab SADARI merupakn skrining dan deteksi kanker payudara yang ampuh dan memenuhi syarat serta sangat efisien. Pemeriksaan yang dilakukan sangat sederhana, ekonomis, tidak menyebabkan sakit dan cepat (Sutjipto, 2003). Diagnosis 
awal SADARI dan pengobatan yang tepat sangat memungkinkan penyembuhan kanker secara total ( Dixon dan Leonart, 2002 ). Wanita yang tampak sehat dan tidak terdapat keluhan pada payudaranya, belum tentu ia tidak terkena kanker payudara oleh sebab itu sebaiknya pemeriksaan payudara sendiri dan dilakukan secara rutin sangat diperlukan (Cahyani, 2000).

Pada kenyataannya, deteksi dini kanker belum populer di Indonesia, karena ketidaktauan, ketidakpedulian dan ketidakmampuan finansial, dan banyak anggota masyarakat yang takut menghadapi kenyataan bahwa ada diantara mereka yang terkena kanker payudara (Sumarny, 2002). Sehubungan dengan masalah kurang memasyaraktnya deteksi dini kanker di Indonesia maka sangat dibutuhkan usaha penanggulangan secara terpadu dengan melibatkan bidang medis dan ilmiah, pemerintah serta masyarakat untuk mengatasi dan menghadapi penyakit kanker yang merupakan momok bagi kita semua (Sumarny, 2002). Minat masyarakat untuk melakukan pemeriksaan SADARI masih sangat rendah, hal ini banyak dipengaruhi oleh ketidaktahuan wanita akan bahaya kanker payudara, sedangkan pengetahuan masih dipengaruhi oleh pendidikan maupun ekonomi. Selain masih banyaknya anggapan bahwa penyakit kanker tidak bisa disembuhkan sehingga ada rasa takut untuk melakukan SADARI. Adanya cerita yang disampaikan oleh oranglain bahwa pemeriksaan SADARI tidak cukup berguna bagi mereka apalagi yang masih berusia dibawah 30 tahun, sehingga menimbulkan keraguan untuk melakukan SADARI.

\section{Kesimpulan Dan Saran}

Kesimpulan

1. Rata-rata skor minat sebelum dilakukan penyuluhan masih rendah yaitu 51,8 dengan skor terendah 28,0 dan skor maksimal 66,0 . Sedangkan berdasarkan kategori minat melakukan pemeriksaan payudara sendiri diketahui bahwa lebih dari separuh wanita usia subur mempunyai minat kategori cukup (31 orang atau $72,1 \%$ )

2. Setelah diberikan penyuluhan tentang kanker payudara dan SADARI selama 1 jam, menunjukkan adanya peningkatan minat wanita usia subur untuk melakukan SADARI yaitu sebanyak 20 orang atau $46,5 \%$. Dan berdasarkan hasil uji statistik diketahui bahwa pemberian penyuluhan kanker payudara mempunyai pengaruh yang bermakna terhadap minat melakukan pemeriksaan payudara sendiri (SADARI) pada WUS di RSIA Kirana Sidoarjo $(p<\alpha 0,05)$.

\section{Saran}

1. Disarankan kepada para pihak rumah sakit agar memberikan informasi kepada setiap pengunjung rumah sakit terutama wanita usia subur tentang kanker payudara dan SADARI melalui leaflet, poster atau secara langsung melalui Tim Promosi Kesehatan Rumah Sakit (PKRS) secara rutin agar pengunjung memahami dan dapat melakukan pencegahan kanker payudara secara benar

2. Hendaknya WUS dapat menerapkan SADARI secara mandiri, dalam rangka mencegah terjadinya kanker payudara pada stadium lanjut

3. Hendaknya institusi pendidikan dapat memperbanyak sumber informasi tentang deteksi dini maupun pengobatan kanker payudara dan bekerja sama dengan pelayanan kesehatan untuk mengadakan bakti sosial di 
masyarakat dengan mengirimkan mahasiswa untuk melakukan penyuluhan kesehatan dengan didampingi dosen maupun tenaga kesehatan.

4. Hendaknya tenaga kesehatan seperti bidan atau perawat setempat bekerja sama dengan puskesmas untuk mengadakan penyuluhan kesehatan kepada masyarakat pada saat acara PKK maupun pengajian dengan strategi yang lebih menarik masyarakat misalnya dengan memberikan pengobatan gratis sesudah melakukan penyuluhan. Hendaknya dapat dilakukan penelitian lebih lanjut dengan metode pendidikan kesehatan yang lebih menarik masyarakat seperti dengan menampilkan video caracara melakukan SADARI

\section{DAFTAR PUSTAKA}

Andrews, Gilly. 2012. Buku Ajar Kesehatan Reproduksi Wanita. Jakarta : EGC

Ibrahim et.,al. 2003. Penyuluhan dan Konseling. Jakarta: Graha IImu

Layton, handoyo. 2001. Definisi minat. http://WWw. fisioterapimakassar. info/ defenisi-minat.html. diakses tanggal 25 februari 2014.

Mendatu, A. 2007. Pendidikan Multikultur.

http://smartpsikologi.blogspot.c om. Diakses tanggal 25 februari 2014.

Ngalim, Purwanto. 2006. Psikologi Pendidikan. Bandung : PT. Remaja Rosda karya.

Notoatmodjo, Soekijdo. 2010. Metodologi : Penelitian
Kesehatan. Jakarta: Rineka Cipta.

2007. Promosi kesehatan dan ilmu perilaku. Jakarta : Rineka Cipta

NS Sallika. 2010. Serba-Serbi Kesehatan Perempuan. Jakarta: Bukune.

Nurcahyo, Jalu. 2010. Awas bahaya kanker rahim dan kanker payudara. Yogyakarta: Wahana Totalita Publisher.

Nursalam. 2009. Konsep Dan Penerapan Metodologi Penelitian IImu Keperawatan. Jakarta : Salemba Medika.

Rasjidi, Imam. 2010. 100 Questions And Answer Kanker Pada Wanita. Jakarta : PT Elex Media Komputindo.

Riskesdas, $2007 . \quad$ www. Riskesdas.com. Diakses tanggal 25 februari 2014.

Rosetha, Sara. 2009. Pemeriksaan Payudara Sendiri. Jakarta : Bukune

Setiana, L. 2005. Teknik Penyuluhan dan Pemberdayaan Masyarakat. Bogor : Ghalia Indonesia

Shaleh, Abdul Rahman. dan Wahab Muhbid Abdul. 2004. Psikologi pendidikan. Jakarta: Sinar Grafik.

Soemitro, Monty dan Hermawan Aksan. 2012. Blak-blakan Kanker Payudara. Bandung: Qanita.

Soedijarto. 2008. Landasan dan Arah Pendidikan Nasional Kita. Jakarta : Kompas 
Sutjipto. $2001 . \quad$ Jurnal.

http.www.depdiknas.go.id.

Diakses tanggal 24 februari 2014.

Tilong, Adi. 2012. Cegah Kanker dengan Anggur. Sampangan: Diva Press.

Varney, Helen, dkk. 2008. Buku Ajar Asuhan Kebidanan Edisi 4 Volume 2. Jakarta : EGC 